\title{
Compressive properties of cell structures manufactured by photo-curing technology liquid polymer resins - Polyjet Matrix
}

\author{
Wytrzymałość na ściskanie struktur komórkowych \\ wytwarzanych techniką fotoutwardzania \\ ciekłymi żywicami polimerowymi - Polyjet Matrix
}

\section{MATEUSZ RUDNIK*}

The article presents the results of compressive strength tests of cylindrical samples with a hexagonal cell structure. The samples were made of MED 610 material using the photo-curing technology liquid polymer resins. The compressive strength was estimated on the basis of a static compression test of the printed elements. It has been shown that the PolyJet Matrix 3D printing technology enables the printing models with a thin-walled cell structure, which, while maintaining the appropriate strength properties, can be used in the design and production of certain utility models.

KEYWORDS: 3D printing, PolyJet Matrix, compressive properties, cell structures

Przedstawiono wyniki badań wytrzymałości na ściskanie próbek cylindrycznych o heksagonalnej strukturze komórkowej. Próbki wykonano z materiału MED 610 z zastosowaniem techniki fotoutwardzania ciekłych żywic polimerowych. Wytrzymałość na ściskanie oszacowano na podstawie statycznego testu ściskania elementów drukowanych. Wykazano, że technologia druku PolyJet Matrix 3D umożliwia drukowanie modeli o cienkościennej strukturze komórkowej, co - pod warunkiem zachowania odpowiednich właściwości wytrzymałościowych - może być wykorzystane przy projektowaniu i produkcji niektórych wzorów użytkowych.

SŁOWA KLUCZOWE: druk 3D, PolyJet Matrix, właściwości ściskające, struktury komórkowe

\section{Introduction}

Additive technologies enable the production of complex and small models with cell structures. This is important especially in terms of saving materials while maintaining mechanical properties. The manufacture of cell structures may be based on the formation of hollow shells which may be like trusses or hexagonal structures with a changed angle of inclination of the arms [1]. Cell structures can also be made by alternating the use of hard and soft materials, which due to the photo-curing effect, will create one model from two materials [3-5]. In one of the articles, models with hexagonal and square structures were investigated in terms of compression and temperature effects. A square structure and two hexagonal structures with different angles of inclination of the arms were compared. It was shown that hexagonal structures overlapped and square structures were broken. Each structure, under the influence of temperature $\left(70^{\circ} \mathrm{C}\right)$, returned to the state before the compression test [2].

The unconventional shapes of structures were used in many articles. In the next article, the research team from Monterrey described the cube-shaped models with fractal structures. The models were subjected to compression procedures and basic mechanical properties were determined [6]. It is advisable to continue research on hexagonal cell structures and the use of PolyJet Matrix technology for this purpose, because the accuracy of the printout and the development of a model of the cell structure will significantly affect the appropriate lower exploitation of materials in industry or medicine without significantly deteriorating mechanical properties.

\section{Samples preparation and measurement technology}

To test the strength properties 10 solid cylindrical samples and 10 samples with a thin-walled hexagonal cell structure were used. The shape of the structure is based on a regular hexagon. The wall of the sample and the thickness of the structure are $1 \mathrm{~mm}$, and the height of the models is 10 (fig. 1).

Models were made in Solidworks. The samples were saved by .stl files (Stereolitography language), which saved in a resolution adjusted to a tolerance of $0.0009 \mathrm{~mm}$ and an angle of $5^{\circ}$. For the model with a cellular structure, mesh onsisting of 1312 triangles

Fig. 1. Sample dimensions

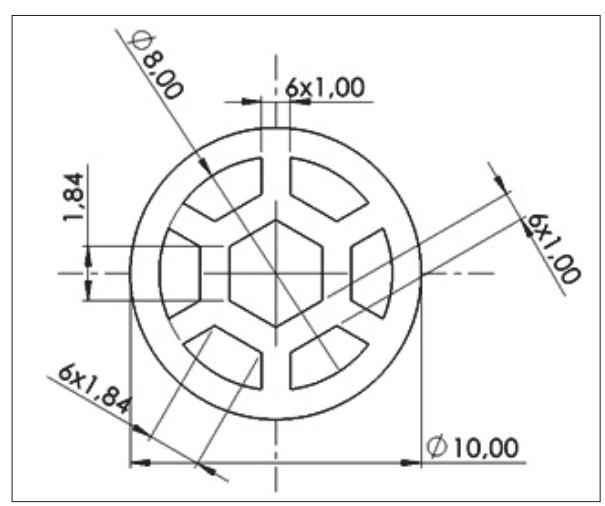

* Mgr inż. Mateusz Rudnik, mrudnik@tu.kielce.pl, 0000-0001-5096-608X - Faculty of Mechatronics and Mechanical Engineering, Kielce Univeristy of Technology, Kielce, Poland 
was generated in the case of solid samples with 664 triangles (fig. 2).

All samples were made in the $X Y$ plane of MED 610 material with an accuracy of $16 \mu \mathrm{m}$ in the PolyJet Matrix (PJM) technology on a Connex 350 printer. The photo-curing technology of polymer resins enables printing of such structures with high accuracy (fig. 3).

The Connex 350 printer in PJM technology uses a block of heads (6) which moves along the guides along $O X(1)$ and $O Y(2)$ axes. Model (8) and supporting material (7) is sprayed layer by layer with a given accuracy on the work platform (4), which lowers with the application of each layer along the guide on the $O Z$ axis (3). Each of the layers of model and suport material is photo-cured using UV lamps (5) that are located on both sides of the head block (fig. 4) [3-5].

The PolyJet Matrix technology uses materials what show biocompatibility, including MED 610. The biocompatibility relates to the polymerized material and not to the process itself. The material is suitable for medical and dental applications. According to the manufacturer, the model made of this material can remain in contact with the skin for up to 30 days, and with the mucosa for up to 24 hours. The material was made in accordance with the standards that take into account chemical characteristics (EN ISO 1099318:2009) [7], genotoxicity (EN ISO 10993-3:2014) [8], type IV irritation and hypersensitivity (EN ISO 1099310:2013) [9] and cytotoxicity (EN ISO 10993-5:2009) [10]. The properties and composition of the material are available on the manufacturer's website $[11,12]$.

Compression tests were performed using the Inspekt Mini testing machine with LabMaster software. The machine is characterized by the fact that the maxi-

a)

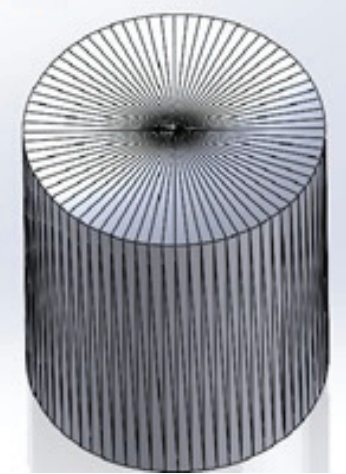

b)

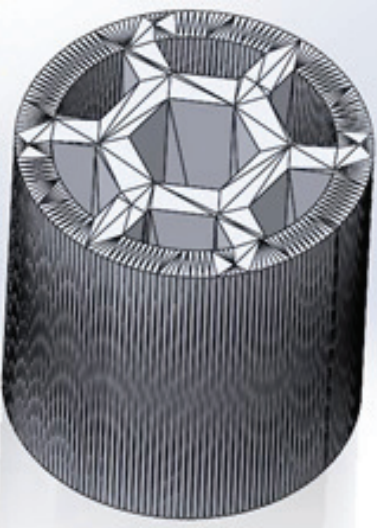

Fig. 2. Samples in stereolitography language (.stl): a) MED 610 sample without cell structure; $b$ ) sample with cell structure

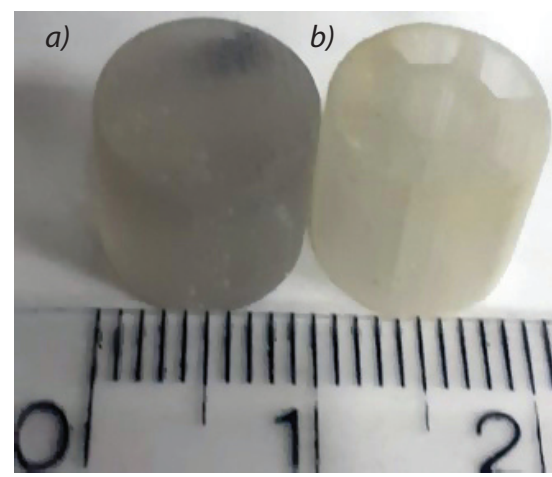

Fig. 3. Samples printed from MED 610: a) MED 610 sample without cell structure; $b$ ) sample with cell structure
Fig. 4. Construction and principle of operation of PolyJet Matrix

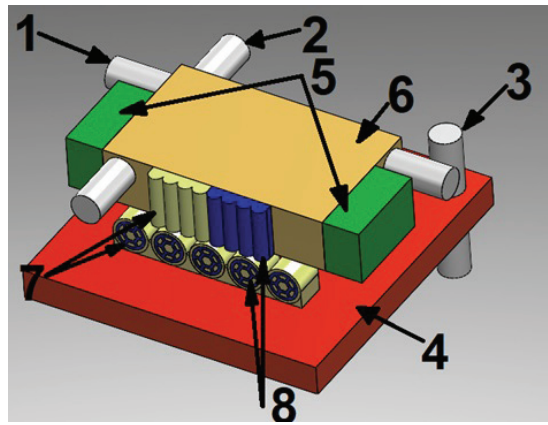

Fig. 5. The specimen placed between the plates prior the compression test

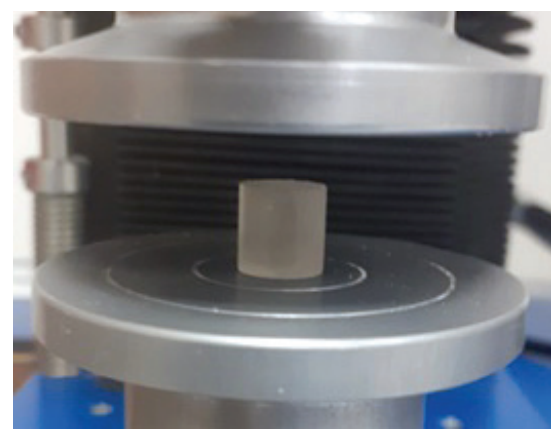

mum loading force is $3 \mathrm{kN}$, and the maximum travel without the handles and the force sensor is $850 \mathrm{~mm}$. Position measurement resolution is $0.001 \mathrm{~mm}$. The compression test consisted of uniaxial loading of each of 10 specimens with a hexagonal cell structure at a speed of $1 \mathrm{~mm} / \mathrm{min}$ until the load drops by $10 \%$ from the maximum set load. An oscillating plate was used to ensure good adhesion of the plate plane to the surface of the samples. Figure 5 shows the mounting of the sample in the plates of the testing machine [13].

\section{Results}

On the basis of fig. 6 it was found that the results of the test of samples 1, 2 and 7 differ from the others. The maximum load for these samples is much lower, as shown in the table, compared to the other samples.

By analyzing the table, it was found that the samples with the hexagonal cell structure achieved the maximum load in the range of $2500 \div 2700 \mathrm{~N}$. The highest load was recorded for sample 10 and the lowest for sample 7. In the case of samples 1, 2 and 7, the deformation exceeded $2 \mathrm{~mm}$ with the assumed condition

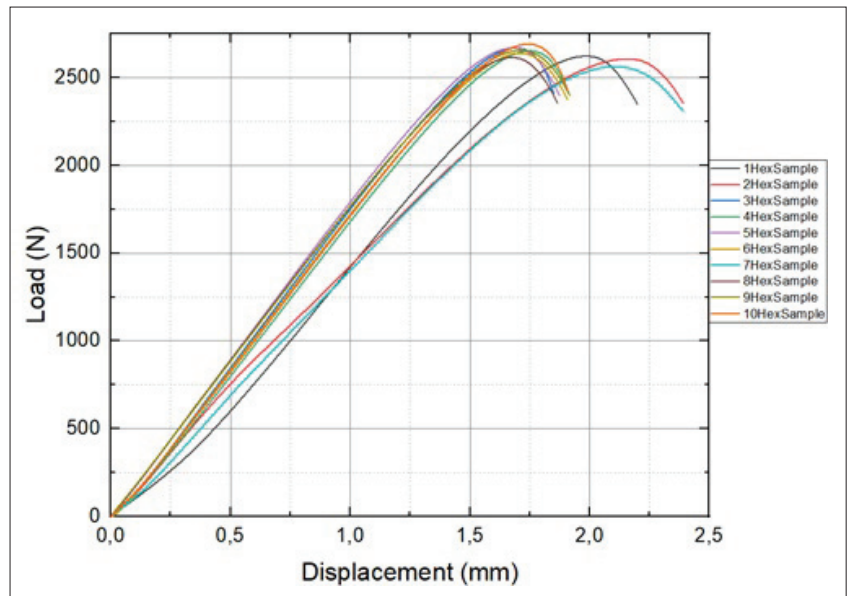

Fig. 6. Plot Load - displacement for 10 samples with hexagonal cell structure 
TABLE. Characteristics of hexagonal and MED 610 samples

\begin{tabular}{|c|c|c|c|}
\hline \multirow{2}{*}{ No. } & \multicolumn{2}{|c|}{ Hexagonal Samples $(A)$} & MED 610 Samples $(B)$ \\
\cline { 2 - 4 } & $\begin{array}{c}\text { Load Max. } \\
{[\mathrm{N}]}\end{array}$ & $\begin{array}{c}\text { Max. displacement } \\
\text { after 2500 N } \\
{[\mathrm{mm}]}\end{array}$ & $\begin{array}{c}\text { Max. displacement } \\
\text { after 2500 N } \\
{[\mathrm{mm}]}\end{array}$ \\
\hline 1 & 2623.1 & 1.77 & 1.20 \\
\hline 2 & 2607.8 & 1.91 & 1.29 \\
\hline 3 & 2668.7 & 1.48 & 1.22 \\
\hline 4 & 2652.8 & 1.54 & 1.22 \\
\hline 5 & 2668.9 & 1.46 & 1.26 \\
\hline 6 & 2639.0 & 1.52 & 1.15 \\
\hline 7 & 2562.6 & 1.92 & 1.17 \\
\hline 8 & 2614.7 & 1.50 & 1.14 \\
\hline 9 & 2654.7 & 1.49 & 1.19 \\
\hline 10 & 2691.5 & 1.50 & 1.14 \\
\hline $\bar{x}$ & 2640.08 & 1.59 & 1.20 \\
\hline $\mathrm{s}^{2}$ & 39.31 & 0.19 & 0.05 \\
\hline Max. & 2691.5 & 1.92 & 1.29 \\
\hline Min. & 2562.6 & 1.46 & 1.14 \\
\hline
\end{tabular}

that the test would be terminated when the load drops by $10 \%$ from the maximum value.

On the basis of fig. 7, it was found that during the compression test with the load ending the test, i.e. $2500 \mathrm{~N}$, three groups were created. The first is the group with all MED 610 samples where all the values are in the cluster defined by the standard deviation of $0.05 \mathrm{~mm}$. The next two groups are samples made of MED 610 material containing cell structure. One of the groups are samples 1, 2 and 7 which are significantly faster under the loading force, distinguishing themselves from other samples, significantly affecting the mean value and standard deviation compared to

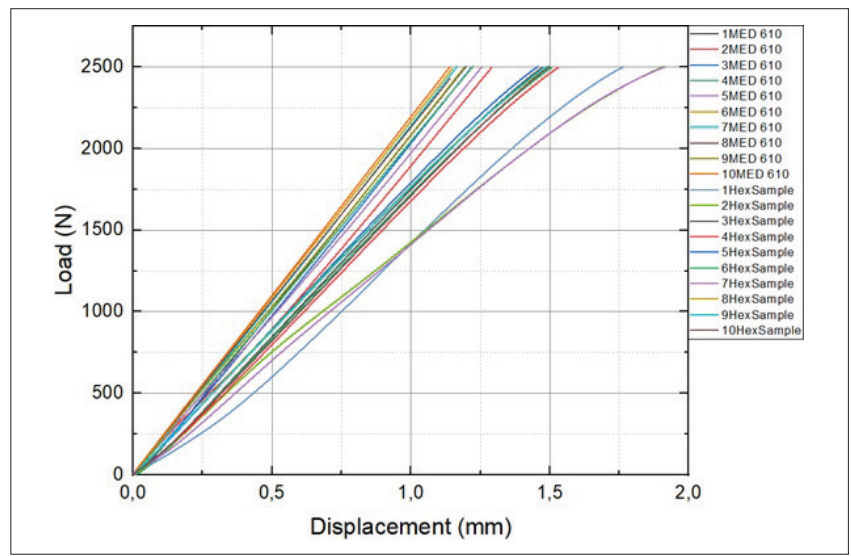

Fig. 7. Plot Load - Displacement for 20 samples

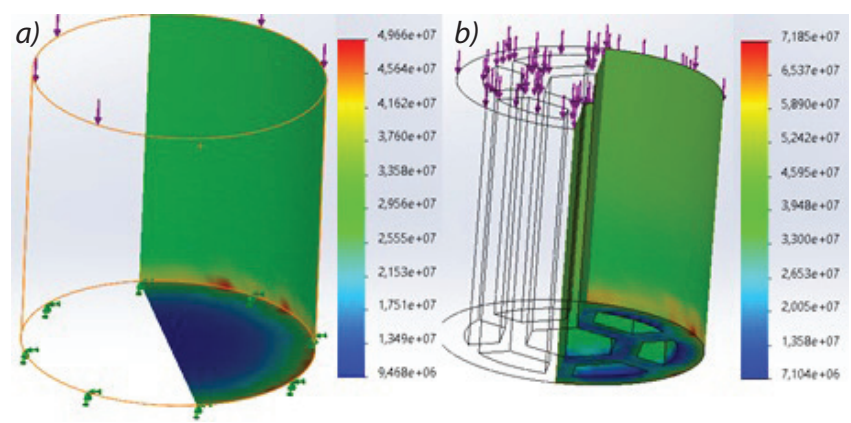

Fig. 8. Samples in Solidworks Simulation: a) sample MED 610 without cell structure; $b$ ) sample with cell structure other samples, which stay close together as the load increases.

The simulation showed that during the compression test for $F=2500 \mathrm{~N}$, the cross-sections of the samples are deformed, however the highest load is assumed by the lower segment of each of the samples. In the case of a cellular structure, it is distributed over the thin walls of the sample and the millimeter walls of structure, and in the case of a full sample the force increase is almost evenly distributed (fig. 8).

\section{Conclusions}

Based on the obtained results for samples with hexagonal cell structures, in the configuration shown in fig. 1, it was found that with increasing load, a visible change in strain occurs, which significantly differs between full and hexagonal samples. The results of the research suggest that filling such a structure with hard or soft material may significantly affect the mechanical properties, which may be the subject of further research in this area

\section{REFERENCES}

[1] Hong H., Hu M., Dai L. "Dynamic mechanical behavior of hierarchical resin honeycomb by 3D printing”. Polymers (Basel). (2021), https://doi.org/10.3390/polym13010019.

[2] Zeng C., Liu L., Bian W., Leng J., Liu Y. "Compression behavior and energy absorption of 3D printed continuous fiber reinforced composite honeycomb structures with shape memory effects". Addit. Manuf. (2021), https://doi. org/10.1016/j.addma.2021.101842.

[3] Kozior T. "Rheological properties of polyamide pa 2200 in sls technology". Teh. Vjesn. 27 (2020): 1092-1100, https://doi.org/10.17559/TV-20190225122204.

[4] Kozior T., Kundera C. "Viscoelastic properties of cell structures manufactured using a photo-curable additive technology - PJM". Polymers (Basel). 13 (2021), https://doi. org/10.3390/POLYM13111895.

[5] Bochnia J., Błasiak S. "Anisotrophy of mechanical properties of a material which is shaped incrementally using PolyJet technology" in: Zolotarev I., Radolf V. eds., "Engineering Mechanics". Kielce (2016).

[6] Álvarez-Trejo A., Cuan-Urquizo E., Roman-Flores A., Trapaga-Martinez L.G., Alvarado-Orozco J.M. "Bézier-based metamaterials: Synthesis, mechanics and additive manufacturing". Mater. Des. (2021), https://doi.org/10.1016/ j.matdes.2020.109412.

[7] EN ISO 10993-18:2009 Biological evaluation of medical devices - Part 18: Chemical characterization of materials (2009).

[8] EN ISO 10993-3:2014 Biological evaluation of medical devices - Part 3: Tests for genotoxicity, carcinogenicity and reproductive toxicit (2014).

[9] EN ISO 10993-10:2013 Biological evaluation of medical devices - Part 10: Tests for irritation and skin sensitization (2013).

[10] EN ISO 10993-5:2009 Biological evaluation of medical devices - Part 5: Tests for in vitro cytotoxicity (2009).

[11] "Stratasys MSDS Clear Bio-Compatible MED610". Available online: https://www.sys-uk.com/wp-content/uploads/2016/01/MSDS-Clear-Bio-Compatible-MED610English-US-1.pdf.

[12] "Stratasys Biocompatible Clear MED610". Available online: https://cadxpert.pl/wp-content/uploads/2019/03/ spec_PolyJet_MED610_MED620.pdf.

[13] Adamczak S., Bochnia J., Kundera C. "Stress and strain measurements in static tensile tests". Metrol. Meas. Syst. 19 (2012): 531-540, https://doi.org/10.2478/v10178012-0046-3. Unauthenticated. 